\title{
Improved propagation methods to raise the productivity of yam (Dioscorea rotundata Poir.)
}

\author{
B. A. Aighewi ${ }^{1}$ (D) $\cdot$ R. Asiedu ${ }^{1} \cdot$ N. Maroya $^{1} \cdot$ M. Balogun ${ }^{1,2}$
}

Received: 8 August 2014 / Accepted: 9 June 2015 /Published online: 2 July 2015

(C) The Author(s) 2015. This article is published with open access at Springerlink.com

\begin{abstract}
White Guinea yam (Dioscorea rotundata Poir.) is an important staple to millions of people in West Africa. Obtaining good quality planting material for yam cultivation is a major challenge. Multiplication ratios are low, and seed tubers are prone to contamination with pests and pathogens in the traditional systems of production. Some approaches to producing quality seed of yam are as follows: farmers select small whole tubers from a ware crop harvest; stimulate the production of seed tubers by 'milking' ware tubers while the leaves of the plant are still green (double harvest system); cut ware tubers into setts about the same sizes as regular seed tubers; or use the 'Anambra' system where smaller setts are cut and used to produce seed tubers. New methods that have been developed to address some of the challenges of quantity and quality of seed tubers are not yet widely applied, so farmers continue to use traditional methods and save seed from a previous harvest to plant the ware crop. This document presents an overview of traditional and modern methods of seed yam production and gives a perspective for the future. Among the modern methods of seed yam production, only the minisett technique, which uses $25-100 \mathrm{~g}$ tuber pieces, is currently used at farmer level, although on a limited scale. While tissue and organ culture techniques are the most rapid methods of multiplying disease free propagules, their limitations include high costs, need for skilled personnel and specialized equipment. The aeroponics and temporary immersion bioreactor methods of producing seed yam are relatively new, and still need more research. To build and sustain a viable seed yam production system, a
\end{abstract}

B. A. Aighewi

b.aighewi@cgiar.org

1 International Institute of Tropical Agriculture, Ibadan, Nigeria

2 University of Ibadan, Ibadan, Nigeria multiplication scheme is required that combines two or more methods including tissue culture for cleaning the seed stock.

Keywords Seed yam $\cdot$ Dioscorea rotundata $\cdot$ Propagation methods

\section{Introduction}

Of the 600 species of the genus Dioscorea, the most important edible species are $D$. rotundata (white yam), D. alata (water yam), D. cayenensis (yellow yam), D. dumetorum (bitter yam), D. esculenta (Chinese yam), and D. bulbifera (aerial yam). Among these, D. rotundata is the most preferred and cultivated, accounting for a large proportion of yam production in West Africa, a region which produces $93 \%$ of the world's yam (FAO 2013).

Traditionally, 'seed' yams or setts (tuber portions) are used for propagation. The yam tuber, which contains a deposit of starch, does not have dormant buds as found on a typical tuber such as potato (Solanum tuberosum). However, at the end of dormancy a meristematic layer of cells beneath the skin of the tuber produces sprouts, usually from the head (proximal) region (Onwueme 1973), indicating that the tuber is ready for planting. Most yam farmers use seed tubers saved from a previous crop for propagation. Due to short supply of quality seed tubers at affordable prices, replacement of stocks of seed yams, which have been infested by pests and diseases, is usually not possible and farmers are forced to recycle poor quality seed yams with the risk of poor yields. Damage from nematodes, viruses, tuber rotting fungi and bacterial infections is a major contributor to the poor seed quality and low yields in yam. A loss in yield of up to $50 \%$ due to viruses has been reported in western Nigeria (Craig 1964, cited in Emehute et al. 1998), while storage losses due to nematodes are estimated at $50 \%$ and may be total, with Scutelonema bradys 
and Meloidogyne spp., which are endemic in West Africa, being the major species responsible (Amusa et al. 2003). Asala et al. (2012) observed that the occurrence of Yam Mosaic Virus (YMV), Cucumber Mosaic Virus (CMV), Yam Mild Mosaic Virus (YMMV) and badnavirus as well as the mixed infections observed in most of the five states and the Federal Capital Territory (FCT) of Nigeria that they surveyed could be attributed to the exchange of infected planting materials between States.

This situation is compounded by the low multiplication ratio of 1:4 to 1:8 for yams (Alvarez and Hahn 1984), which makes it difficult for 'clean' seed tubers to be multiplied rapidly for distribution or sale to farmers and the absence of a formal seed yam system in the entire yam zone of West Africa. This review takes a critical look at various options available for seed yam production, and the prospects for alleviating the problems of poor quality seed yam and availability.

\section{Traditional methods of seed yam production}

In traditional yam cultivation there is no separation of seed and ware yam production. The farmer plants for a ware crop with the knowledge that seed tubers for the next crop will also be produced. The yam crop stays in the field for 8 to 10 months and the tubers are ready to grow after another 2 to 3 months after harvest when dormancy is broken. The traditional methods employed produce planting materials that are expensive and often of poor quality (Nweke et al. 1991; Aighewi 1998). As mostly farmer-saved seed tubers are used, farmers will normally select and plant their good seed tubers and sell any left over (which are usually of poor quality). Seed is only bought if there are unplanted mounds due to a shortage of planting material. Farmers' methods of production are generally characterized by low multiplication ratios (Alvarez and Hahn 1984), with uneven and prolonged sprouting periods when planted (Otoo et al. 1987). Despite these challenges, traditional systems have sustained yam production through the years. They provide the assurance of obtaining seed by farmers, as different methods can be manipulated to suit different cultivars.

Double harvesting or 'milking' This is the most important traditional method of seed yam production in the yam belt of West Africa. It is a system in which the same plant of an early maturing variety is harvested twice. A first harvest is made of tubers meant for food while the shoot of the mother plant is still green. This is usually done between 4 and 5 months after shoot emergence. The mound is opened from one side; the tuber is detached from the base of the vine while keeping most roots intact, and the mound is re-moulded (Fig. 1). The plant initiates production of a new tuber from the base of the vine, which often bulks into an amorphous shape with protuberances or digitations that can be detached and planted separately at harvest. The second harvest is done at the end of the season when the plant senesces (1-3 months after the first harvest) for regenerated tubers to be used solely as seed (Onwueme 1973). Degras (1993) noted that whereas tubers from the first harvest were often infested by nematodes (Scutellonema bradys and Pratylenchus coffeae), those of the second harvest were either slightly or not at all infested. This makes regenerated tubers better planting material than normal setts from single harvests, but the method is labour intensive and only suited to early maturing varieties. The farmer has to make a critical decision of when to do the first harvest so as to have sizeable tubers for the ware yam market without compromising the quantity of seed tubers to be obtained from the second harvest as the same photosynthetic apparatus produces both.

The 'Anambra' system This is practised in some areas close to the banks of the River Niger in Anambra, Edo and Delta States of Nigeria. This is the only region where dedicated seed yam producers are found, and generally better quality seed is produced compared to where other traditional methods of production are used. Small tuber pieces of 80-100 g are cut from post-dormant 'mother' tubers weighing 500-1000 g and planted to produce seed yams (Fig. 2) (Okonmah 1980). The setts are planted directly in the field, almost always in a mixture of other crops such as maize, cassava, cocoyam and vegetables. Some farmers may dust the cut tuber surfaces with wood ash before planting. In this system, the distance between yam plants and depth of planting depend on the density and type of other crops in the mixture and the moisture content of the soil. The challenge of the 'Anambra' system of seed yam production is the high incidence of fungal rots after planting, especially as most farmers do not treat their setts with recommended chemicals before planting (Aighewi 1998). The seed tubers produced by this system are usually planted whole and have better establishment than when cut setts are used as seed.

Cut setts At planting time, yam setts can be obtained by cutting larger ware size tubers into tops, middles and bottoms (Fig. 3) each weighing 200 to 500 g. The setts are planted when cut surfaces are dry; usually after a day or two. Hence only the head portion would have a sprout and it is preferred because it establishes better and faster. It has, however, been observed that this method accounts for severe nematode damage, as infestation by S. bradys and P. coffeae is directly proportional to the age of the plant tissue, decreasing towards the growing zone of the tuber (Degras 1993). Shoots from the middle and bottom portions take longer to emerge after planting because they are not planted with pre-formed sprouting points. Generally, tubers from the cut setts are milked or harvested after seven to 12 months depending on the variety and agro-ecology. Setts that sprout earlier have a longer growth period because the crop is harvested when the dry season sets in and plants senesce. 
Fig. 1 'Milking': 1. Tuber is detached from base of vine; 2 . The vine base is covered again with soil; 3 . Amorphously shaped seed tubers are produced

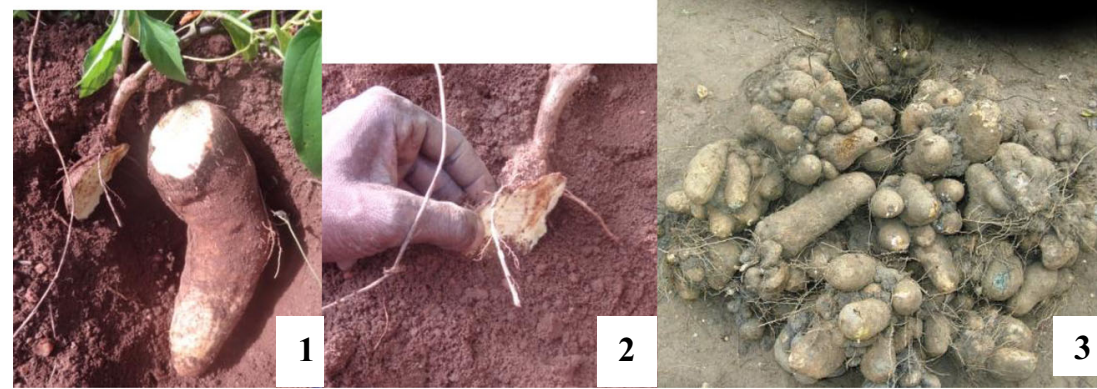

In the Federal Capital Territory (FCT) and some yam producing States of Nigeria such as Niger, Kogi and Nassarawa, some ware sized tubers are cut into sections during the first harvest and buried again with the stump or corm left after milking in the same mound. At the end of the season ( 2 to 3 months later), these setts with well-suberized surfaces but without sprouts, are dug up and planted immediately for the next crop (Aighewi 1998). Sprouting starts only after the dormancy period for the variety is broken. This method is used for the 'Pepa' variety because freshly cut setts are prone to fungal rots when planted during the period of April to May, the normal planting time. Farmers claim that the setts with suberized surfaces rot less than freshly cut ones when planted during hot weather as is done in most parts of the yam growing zone of Nigeria. Farmers in Ikire (Osun state), Nigeria, dig a trench and bury the setts for suberization before planting (Fig. 4). This practice is labour intensive but the setts with healed surfaces are as good as whole seed yams in terms of protection from fungal infections.

Small whole tubers sorted from a ware crop Whole seed tubers are ideal for planting as they have no exposed parenchyma for rapid infection by fungi and they fit very well into farmers' labour management strategy of planting at the beginning of the dry season. In addition to whole seed tubers produced by double harvesting, some varieties produce 1-3 small tubers together with a large ware tuber that is used for food. The small tubers are sorted and reserved for planting (Fig. 5).

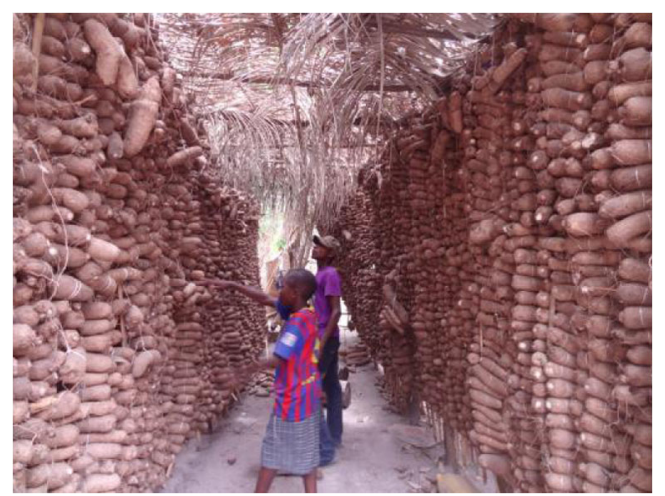

Fig. 2 Traditional storage of seed tubers produced by the 'Anambra' System
The seed sized tubers produced from a ware crop are the reason for the age long custom of using mainly farmer-saved seed in yam production. In this situation, farmers do not consider seed yam as a cost element in yam cultivation and are reluctant to adopt any method to increase seed production or improve their production practices. Small tubers should be used with caution as their size could be due to disease, especially of viral origin which is a major cause of seed degradation. Due to the high cost of seed tubers, most yam farmers will not contemplate roguing. Where diseased plants are not rogued, it is not possible to distinguish diseased and healthy tubers at harvest because viral symptoms are not visible on yam tubers.

\section{Modern methods of seed yam production}

The minisett technique The minisett technique was developed by the National Root Crops Research Institute (NRCRI), Umudike, Nigeria, (IITA 1985) as a modification of the Anambra system through further reduction in the size of the setts planted. The major aim of the technique is to increase the quantity and quality of seed tubers available to farmers. This development was based on the principle that any section of the tuber is capable of developing buds and sprouting provided it has a portion of the periderm (Onwueme 1973).

In the minisett technique, 'mother seed' yams of 500 $1000 \mathrm{~g}$ that have broken dormancy are cut into pieces (minisetts) weighing 25 g (Fig. 6) (Alvarez and Hahn 1984; IITA 1985; Kossou 1990; Kissiedu et al. 1994). The 25 g

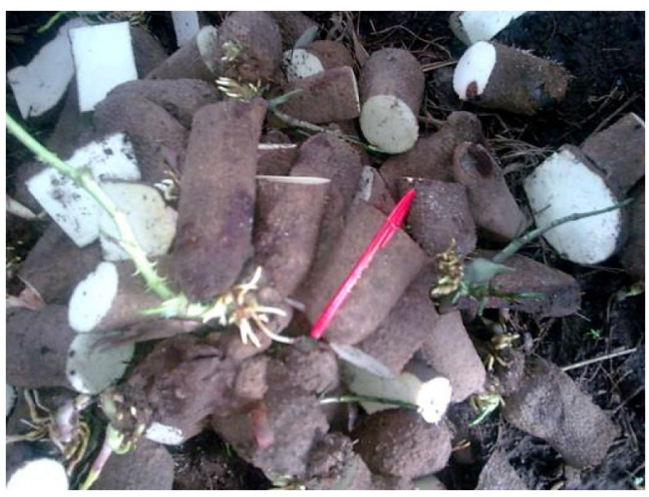

Fig. 3 Large setts used as seed to produce ware plus seed yam 


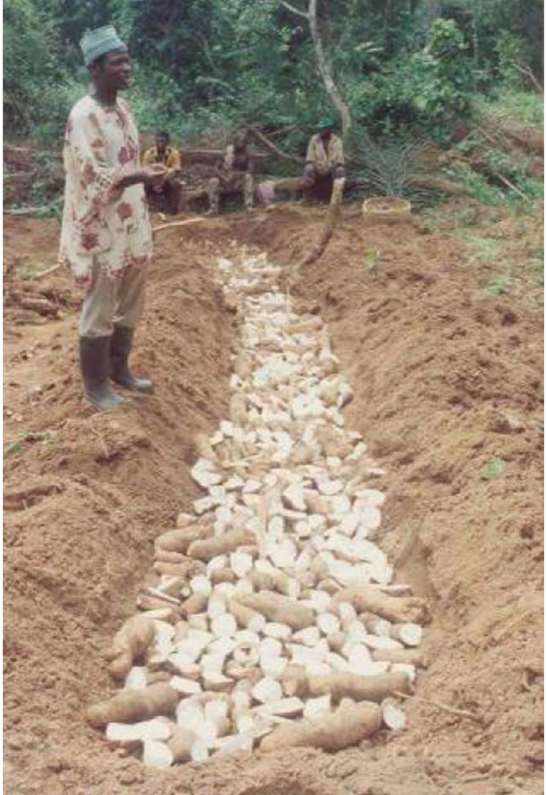

Fig. 4 Yam setts prepared and left in a trench for partial healing of cut surfaces before planting

recommendation was meant to be a compromise between the competing requirements of maximising setts from a single tuber and the need for a reasonable proportion of seed yams in the yield (Kalu et al. 1989), although others have pointed out that larger minisett sizes than $25 \mathrm{~g}$ would be better (George 1990). While there is much variation in the response of $D$. rotundata to the minisett technique (Aighewi 1998), it has been suggested that increasing the size of minisetts of some varieties would enhance their sprouting potential (Ayankanmi et al. 2005). However, Okoli and Akoroda (1995) noted that there is wastage of edible tubers being used for planting, as 5-30 g setts

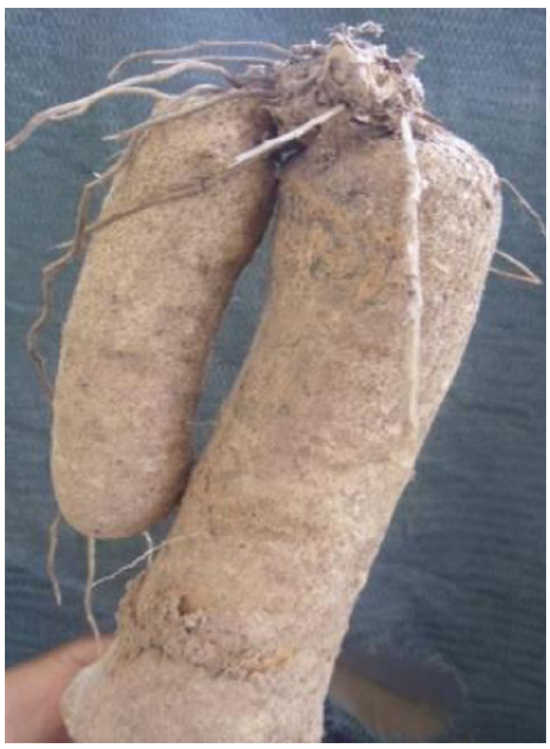

Fig. 5 In varieties with multiple tubers, the small tuber is reserved for seed while the big tuber is used for food could produce the recommended seed yam sizes of $150-300 \mathrm{~g}$ (Akoroda 1985a; Onwueme and Charles 1994). Even $30 \mathrm{~g}$ setts of $5 \mathrm{~mm}$ thickness which are normally discarded as yam peels, yield mean tuber weights above $200 \mathrm{~g}$ (Aighewi 1998).

The freshly cut minisetts are treated in a suspension containing wood ash or fungicide and insecticide, and then spread out in light shade to dry for 1-2 days (IITA 1986). Treatment of setts before planting is influenced by challenges of unavailability, quality and high cost of chemicals. While the use of wood ash as a substitute for fungicide and insecticide has been recommended, its effectiveness has been variable (Otoo 1992). Minisetts can be planted directly in the field on ridges at a depth of 9-12 cm with a plant spacing of $25-30 \mathrm{~cm}$ by $100 \mathrm{~cm}\left(4\right.$ stands per $\left.\mathrm{m}^{2}\right)$ when the rains are well established. Otherwise they could be pre-sprouted in beds, baskets or boxes using top soil, saw dust, shredded coir or carbonated rice husk as media. Sprouting and tuber yield of direct planted setts are strongly affected by variety (Ayankanmi et al. 2005; Aighewi 1998). The condition of the soil at the time of planting also affects the survival of propagules. Although the treated minisetts can be directly planted in the field, it is usually recommended that they are first pre-sprouted in a nursery before transplanting. Pre-sprouting in a medium free of pest and disease can help minisett survival, but it is more labour intensive (Okoli and Akoroda 1995). When minisetts are presprouted, there is a better crop establishment because only sprouted minisetts are transplanted to the field, and this can be timed for a period when the soil is sufficiently wet to support adequate growth. With pre-sprouting, additional time and cost are required to check the minisetts at intervals and select those that have sprouted for transplanting.

Despite advantages of the minisett technique which include fewer ware tubers being used as seed, faster rate of multiplication than with traditional methods, ease of operation as well as potential for production of better quality seed and mechanization, the level of adoption remains low. Some factors responsible for this are the scarcity and high cost of complementary inputs as well as additional costs for cutting and treating minisetts (Chikwendu et al. 1995; Ajieh 2012), and farmer reluctance to buy seed. The minisett technique is meant to produce seed tubers, so its promotion should be directed to dedicated seed yam producers, who exist in only a few yam growing areas. In traditional systems, ware yam farmers will sell seed after their fields are planted and there is surplus, and will buy if there are unplanted mounds due to a shortage of planting material.

Production using microsetts and microtubers In seed yam production the prefix micro is used in relative terms comparing the normal size of about $250 \mathrm{~g}$ to very small setts of $10 \mathrm{~g}$ or less. The same principles and methods used for minisetts also apply to microsetts (Alvarez and Hahn 1984; IITA 1985). According to Alvarez and Hahn (1984), microsett propagation with the aid of phytohormones increased the multiplication ratio of the 
Fig. 6 'Mother seed' yams (500-1000 g) are cut into minisetts (25-30 g), which are planted to produce seed yams

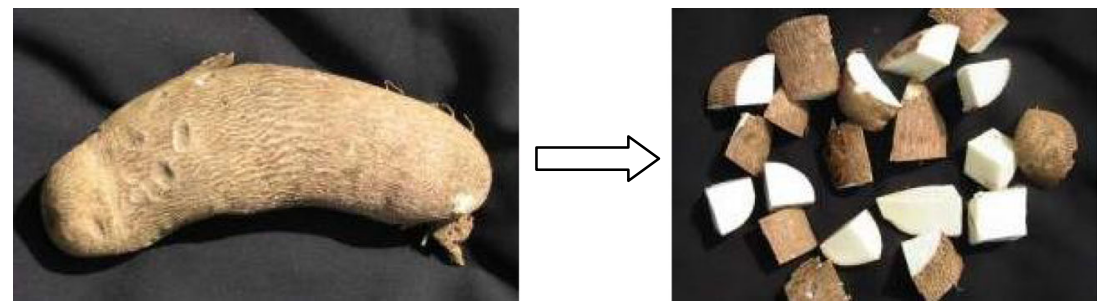

traditional system from 1:4 to 1:90. Tuber weights of $280 ; 240$ and $225 \mathrm{~g}$ were obtained with 60,000, 80,000 and 100,000 plants/ha using $7 \mathrm{~g}$ microsetts of genotype TDr 131 (IITA 1985), and microsett populations could be as high as 3.4 million/ha (Otoo 1992). Compared to other systems, the microsett technique was ranked best with regards to the number and cost of mother tubers needed for seed yam production, and the rate of multiplication (IITA 1985). Although enormous amounts of yam could be saved using microsetts, preparation of setts could be labour intensive. Farmers may not be able to handle the small setts conveniently, and not all varieties may be suitable for use with this technique. If adequate seed treatment (fungicide/insecticide application), is not given before and after planting (mulching/irrigation), the rate of success could be low.

Tissue and organ culture techniques of producing seed yams Plant Tissue Culture (PTC) is the growth of small plant parts in a nutrient medium in laboratory containers such as test tubes to regenerate the complete plant (plantlets). The practice is done in a controlled laboratory environment which is not susceptible to changing weather conditions, such that production cycles can be planned (Yam and Arditti 2009). Clean, high quality and uniform plants can be produced from otherwise unclean mother plants. Tissue culture provides a rapid method of multiplying disease-free improved cultivars for breeding programmes and/or providing planting materials for experimental work. It uses tissues, organs or groups of organs, such as uninodal cuttings from stem fragments (Fig. 7), in vitro plantlets, axillary buds, shoot tips, yam tuber blocks, seeds, and excised embryos to generate whole plants under aseptic conditions (Balogun and Gueye 2013). Selected clones are cleaned from virus diseases through meristem culture combined with thermotherapy, and the regenerated plants are virus indexed ( $\mathrm{Ng} \mathrm{1994).} \mathrm{The} \mathrm{negatively} \mathrm{indexed} \mathrm{plants}$ are then grown under sterile conditions in artificial media containing growth substances such as sugars, vitamins, and plant growth regulators, and multiplied to reach target numbers. Thereafter, they are acclimatized and grown in pots to maturity to give whole seed tubers of high quality after 5-6 months.

The risk of plant losses during acclimatisation and the long period required to produce a seed tuber from tissue-cultured plantlets inspired studies into in vitro tuber production in yams as done for potatoes. Yam microtubers produced from in vitro plantlets were therefore proposed as alternative materials for propagation (Balogun 2009) due to the reduced incidence of diseases, small size and ability to regenerate after dormancy break, by-passing the hardening rigours. However, applicability will depend on the ability of different genotypes to produce microtubers in vitro. Balogun et al. (2004) noted that in vitro tuber production is dependent on interaction among a number of factors including the source of explants, species, growth regulators, photoperiod and genotype. Although in vitro microtuber production has been proposed as an alternative propagation material, some of them were too small and failed to sprout showing the need to control microtuber dormancy (Balogun 2005).

Tissue culture plays an important role in the production and international exchange of disease free planting materials of yams in the form of plantlets and potentially as microtubers, but it has some obvious limitations. These include high costs, the need for skilled personnel and specialized equipment, and more crop cycles are required to produce large quantities of suitable seed size tubers for ware yam production. Although the aseptic steps taken in tissue culture give a higher assurance of quality, reducing the frequency of microbial contamination of tissues can be challenging. There is also a risk of re-infection once the seeds leave the aseptic conditions of laboratories and are transferred to fields where there is high disease pressure.

Use of vine cuttings for seed yam production Recently, yam researchers in West Africa have been focusing on vine cuttings as an alternative to the use of tubers in seed yam production. Rooted vine cuttings of $20 \mathrm{~cm}$ length with 1 to 3-nodes (Acha et al. 2004; Kikuno et al. 2007; Agele et al. 2010) produced mini-tubers of 50-600 g after 8 months giving a 1:30 propagation ratio. Vine cuttings for tuber production should be taken from healthy plants aged between 30 and 60 days after shoot emergence, and before tuber development starts (Okonmah 1980; Kikuno et al. 2007). Cuttings are rooted in a high humidity chamber or carbonized rice husk before transplanting into soil or planting directly in top soil in a garden (Fig. 8). Scientists at the International Institute of Tropical Agriculture in Nigeria, have produced seed yam by planting vine cuttings in vertical grow bags in the screenhouse (Fig. 9). Black polythene bags are filled with soil, tied, and then hung to poles or ropes running across the top of the screenhouse. Depending on the size of the bags, holes are pierced through to allow planting of vine cuttings. Water is supplied to the plants through irrigation pipes or watering cans and minitubers are 
Fig. 7 Tissue and organ culture to produce seed yam: 1 . Field plants; 2. Single nodes from the field for in vitro culture; 3 . Batch of in vitro plantlets in test tubes; 4 . In vitro plantlet
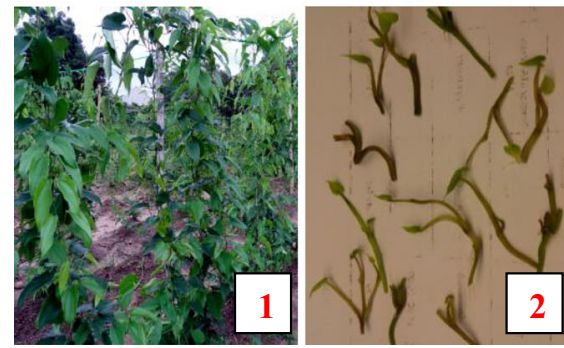

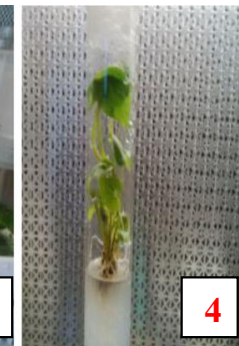

harvested when the plants senesce. This innovation maximizes the use of space in seed production.

While varietal differences in the rooting of vines have been noted, Acha et al. (2004) observed significant increase in the number of roots after treatment with indolebutyric acid. Cabanillas and Martin (1978) noted that using single node cuttings, multiplication of yams could be several hundred fold in 1 year. However, appropriate and cheap methods of large scale rooting of $D$. rotundata are yet to be established, although vine cuttings root well in an aeroponics system. (Maroya et al. 2014).

A major advantage of this method of propagation is that the entire tuber is saved for food, thus improving the economic value of the crop. Moreover, setts produced would be free of nematodes and soil-borne pathogens if a sterilized medium or pest-free soil is used for propagation. Large quantities of small size minitubers that are appropriate for international exchange of germplasm can be produced using vine cuttings, as well as normal seed size tubers for production of ware yam depending on the time of harvest of vines.

Use of a roponics system for seed yam production Aeroponics is a method of growing plants in a soilless environment with very little water (Carter 1942). Techniques for growing plants without soil were first developed in the 1920 s by botanists who used primitive aeroponics to study plant root structure (Barker 1922). This absence of soil made study much easier as the plant's roots dangle midair, with only the stems held in place. Atomizing nozzles ensure the most effective delivery of nutrients, as they turn the water into a fine mist and plants absorb the nutrients through their roots by absorption of compounds through cell walls.

The aeroponics is one of the new technologies implemented for seed yam propagation through the project known as "Yam Improvement for Income and Food Security in West Africa (YIIFSWA)" (Maroya et al. 2014). The first seed yam production using the aeroponics system was successfully carried out by the International Institute of Tropical Agriculture, Ibadan, Nigeria (IITA 2013a). This was done using both pre-rooted and unrooted vine cuttings. One-node pre-rooted vines of approximately 2 months old, as well as two node vines freshly cut from yam seedlings were transplanted into aeroponics boxes established in a screenhouse (Fig. 10). The initial results of both pre-rooted vines and direct planted vines were impressive as plants continued growing normally with development of new roots and shoots. By the third week after planting, 85-100\% of the direct planted vine cuttings produced roots in the aeroponics system and there were differences in response of the 13 yam
Fig. 8 Mini-tuber production from $D$. rotundata through vine cuttings: 1 . Freshly cut vines; 2. Vine cutting rooting after planting: 3. Tuberization of vine cutting; 4. Minitubers produced from vines
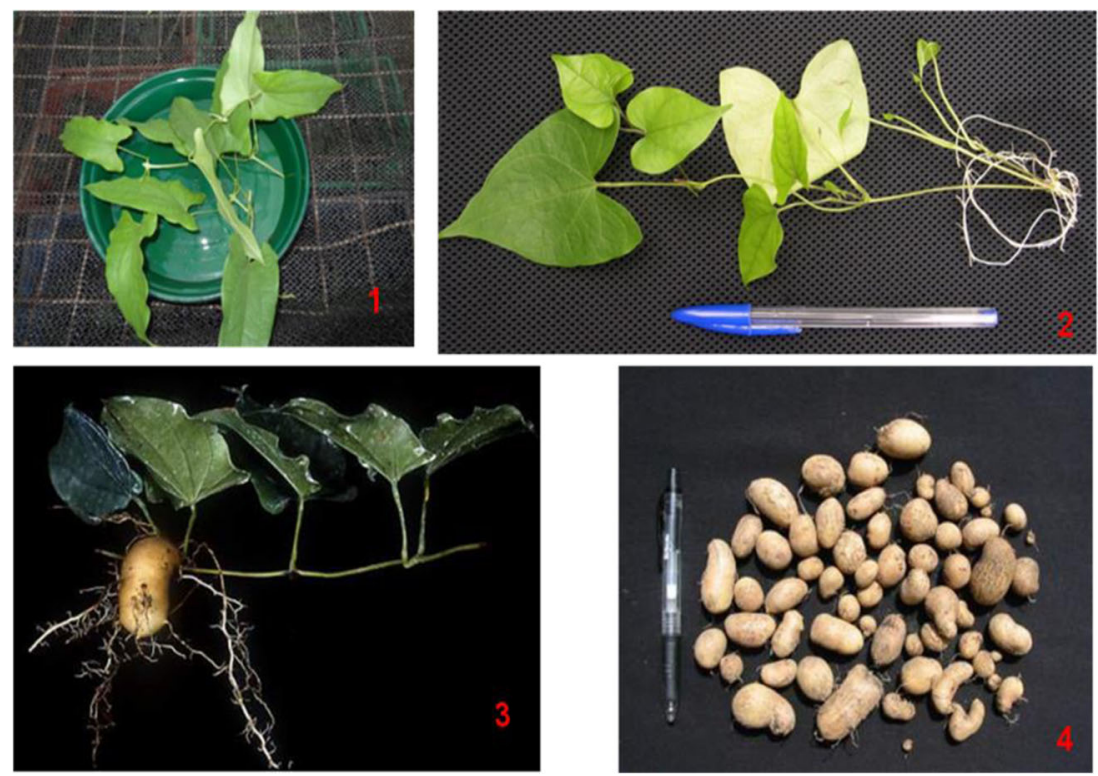


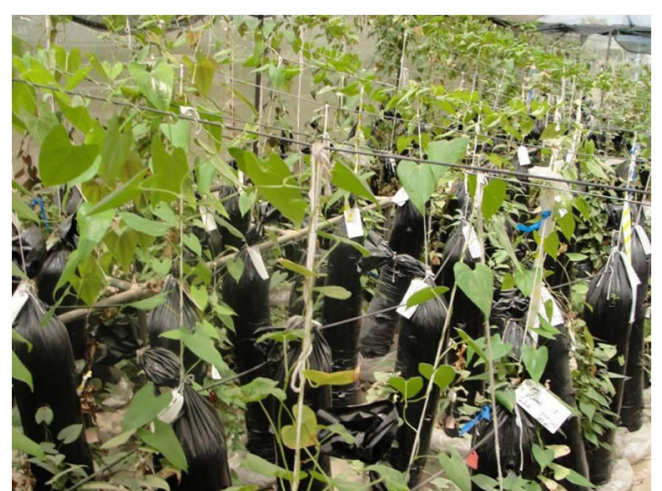

Fig. 9 Vertical grow bags used to produce seed yam

varieties used with regard to rooting and percentage survival (IITA 2013a).

The first setts of microtubers harvested after 4 months of growth ranged from 0.2 to $2.7 \mathrm{~g}$, and some of the plants continued to grow after the first harvest, eventually producing up to $110 \mathrm{~g}$ tubers (IITA 2013b). Some of the plants in the aeroponics system were still growing more than 14 months after planting. When planted in soil, yam plants usually grow for 7-10 months before they senesce. The type of nutrient solution (ammonium phosphate $(1.0 \mathrm{me} / \mathrm{l})$, calcium nitrate $(1.5 \mathrm{me} / \mathrm{l})$, magnesium sulphate $(0.5 \mathrm{me} / 1)$, potassium nitrate $(1.5 \mathrm{me} / 1)$; boron (5 ppm); Mn-EDTA (3 ppm) and Fe-EDTA (8 ppm) used influenced the production of bulbils and microtubers in D. rotundata and $D$ alata (Fig. 11). All the bulbils produced by $D$. rotundata started growing with new shoots and roots as soon as they appeared. Although it is too early to conclude on the rate of seed yam multiplication in aeroponics, it has been noted that the system can spectacularly improve seed yam propagation rates and quality of seed tubers, as the plants grown from tubers produced in the aeroponics system were assessed to be much cleaner (healthier) than those from traditional methods of production (Maroya et al. 2014). There is also the advantage of making several harvests of tubers from the same plant over an extended period of growth. The aeroponics system is not meant for direct use by farmers, it is planned to be useful in the formal seed yam system for prebasic and basic seed production. The full potential and shortcomings of seed yam production by aeroponics will only be determined after a great deal more research on the system, including cost of production, has been carried out.

\section{Use of temporary immersion bioreactor system (TIBs)}

A bioreactor is an enclosed, sterile environment which is provided with inlets and outlets for air flow under pressure and utilizes liquid medium (Watt 2012). It is an advanced tissue culture technology used for differentiated plant tissues. For a long time, bioreactors had been used in scaling up the production of plant secondary metabolites, including those that are of medicinal or health value to humans, using cell suspensions. Different designs of TIBs exist, but most common are the Twin Flask types, having two containers, one for the medium and the other for the cultures (Adelberg and Simpson 2002). This type of TIBs was established at IITA Ibadan, Nigeria to optimize protocols for efficient acclimatization of plantlets from tissue culture, automate micropropagation, and scale-up and enhance microtuber production (Fig. 12). The plant tissues, single node cuttings were immersed in the medium in a timed manner, in terms of frequency and duration of immersion in liquid nutrient to allow for aeration. In TIBs, growth is enhanced compared to tissue culture (Escalona 2006) as immersion in the liquid medium is not continuous. By using TIBs for yam propagation both plantlet and microtuber production has been reported, although sprouting was greater with larger microtubers of $D$. alata (Balogun et al. 2014).
Fig. 10 Minitubers produced from an aeroponics system: 1 . Two-node cutting prepared for planting; 2. Plants growing in the system; 3. Rooting and tuberization of cuttings; 4 Multiple tubers produced on a cutting; 5 . Harvested tubers

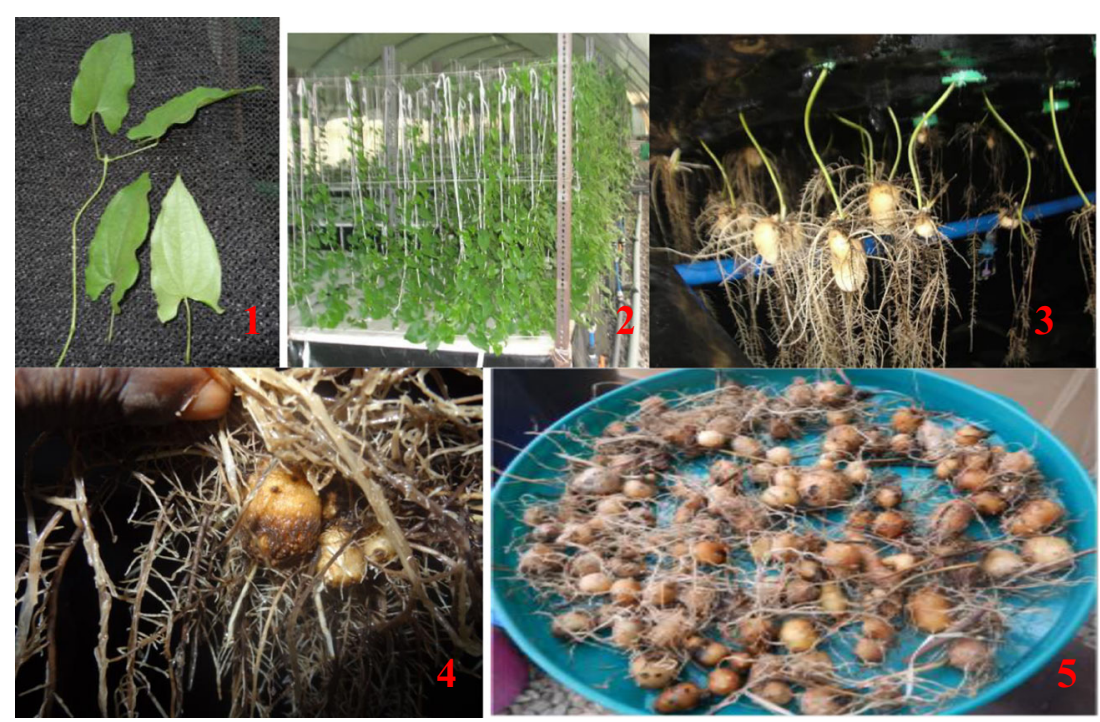




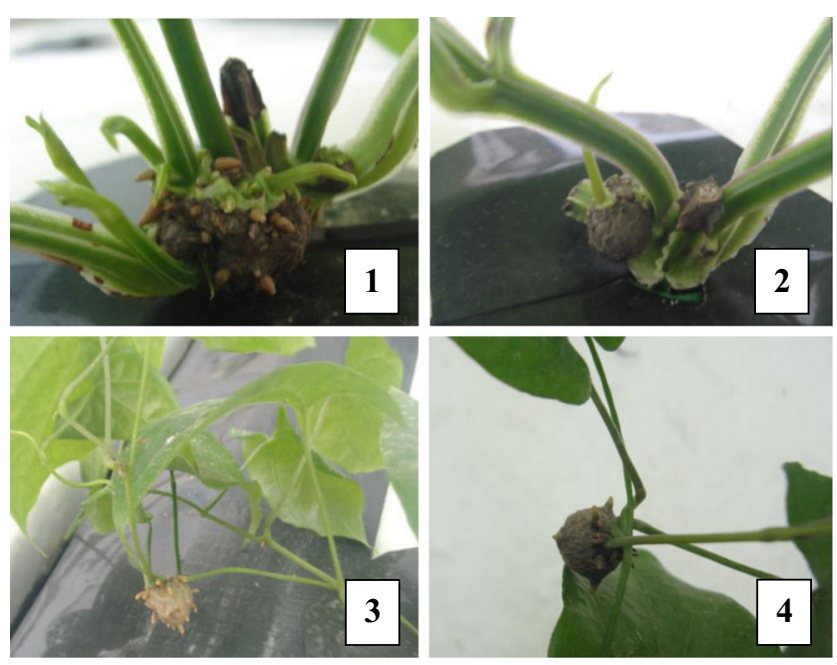

Fig. 11 Bulbils on D. alata ( 1 and 2 ) and D. rotundata (3 and 4 ) plants in the aeroponics system

In both conventional tissue culture and the TIBs, plant tissues are fed a ready-made carbon source which makes the process heterotrophic. The ready-made carbon source e.g., sucrose, supports the growth of microbial contaminants in addition to that of the plants, making contamination control quite challenging. Photoautotrophic micropropagation is now being advocated as little or no sucrose is used, in addition to better aeration achieved in TIBs. Larger vegetative structures, such as tubers, can be obtained when plants are grown in TIBs, but photoautotrophically. In the latter, sucrose is partially or completely replaced with carbon dioxide (Xiao and Kozai 2004; Curtis 2005a, b). This imitates a natural field environment with little or no contamination and high yields. This suggests that even larger microtubers can be produced and planted directly in the field. However, it will be necessary to standardize protocols for direct field planting of D. rotundata microtubers from TIBs (Balogun et al. 2014). Advantages of TIBs include faster growth and acclimatization of plantlets due to more vigorous plantlets which are better able to withstand the shock of transplanting. The implication of this is more clean seed of yam in the shortest possible time.
However, a major disadvantage of TIBs is the cost of investment and that of the seeds produced using the technology. Although the seeds are premium, there is a limit to the unit cost for it to compete well. Therefore, low-cost technologies for photoautotrophic bioreactor systems are being explored as has been done for cocoa (Curtis 2013; Shaw 2012).

Use of botanic seeds for seed yam production In the past there were difficulties in germinating yam seeds due to a failure to recognize their dormancy period, and because many seeds lack well developed embryos and endosperms (Sadik and Okereke 1975). Efforts to improve $D$. rotundata through hybridization are usually frustrated by low rate of flowering, lack of synchronization in flowering, very small flowers which are not easily accessible, irregular flowering, very low rate of fruit set, and sometimes poor seed germination (Onwueme 1973; Akoroda 1985b). Some of these problems could be resolved by using varieties which naturally flower freely and are fertile, together with having a good knowledge of the combining ability of parents. Among the different methods of seed yam production used by Alvarez and Hahn (1984), botanic seeds (Fig. 13) gave the highest yield per unit area.

The use of botanic seeds for large-scale seed yam production would save the tubers for food, and greatly reduce the risk of tuber-borne diseases. Botanic seeds provide a wider scope for crop improvement and seed handling while storage would be less cumbersome. However, the problems envisaged in this method of production could be the wide variation in seedling tuber size, colour, shape and quality as yam is an out crossing species. The need for horticultural expertise, insufficient information on nursery practices, increase in labour input, a longer season to attain maximum yield or appropriate seed tuber size are other issues that could hinder large scale use of botanic yam seed.

\section{Relative efficiency of each technology}

All the technologies described above should have different users based on their respective interests and expertise.
Fig. 12 Yam plants in temporary immersion bioreactor system
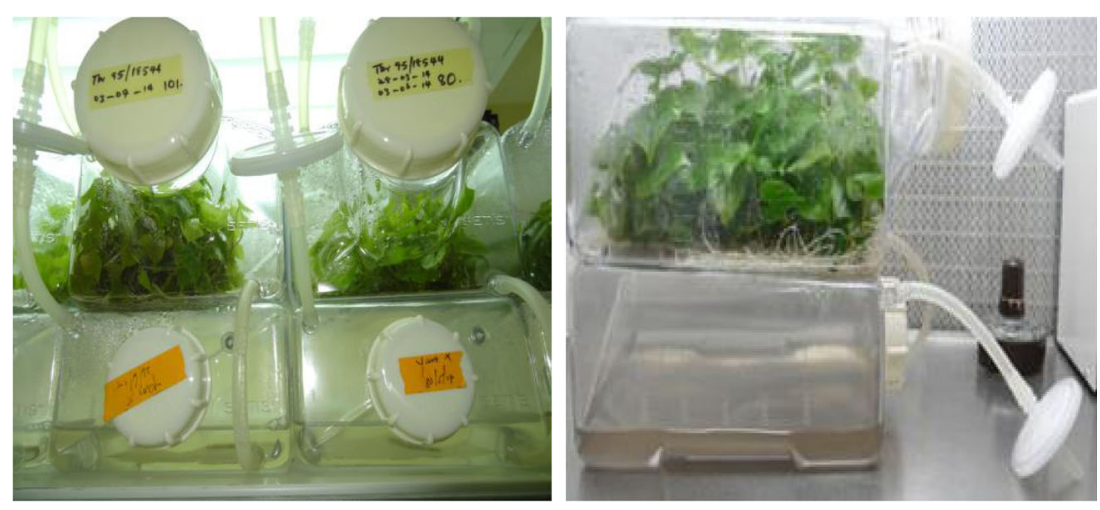


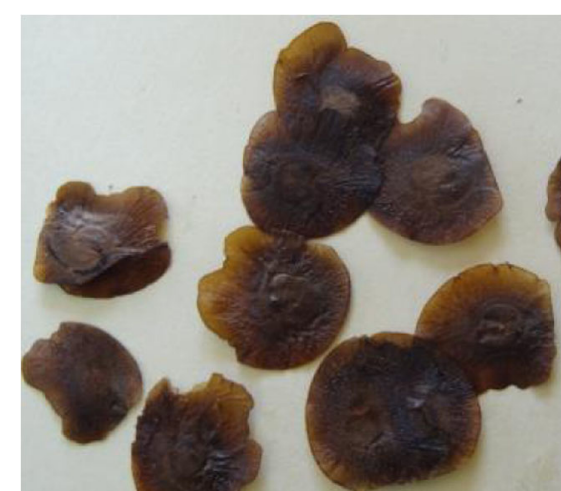

Fig. 13 Botanic seeds of yam

Irrespective of the propagation technique used, it is necessary to determine the attributes of the products in terms of quality, yield (numbers versus weight), percentage survival after planting, cost, and multiplication ratio per unit time in a particular agro-economy when deciding the technology to adopt (Balogun and Gueye 2013). A major factor determining the quality of seed yam is the presence or absence of virus. Being vegetatively propagated, any virus in the source material will be multiplied in the field, and this has been a major challenge in the use of farmer-saved seed yam. Table 1 gives a summary of some characteristics of various seed yam production methods. The table does not attempt to make a thorough comparison because several other factors not mentioned also affect the product from different systems. For example, different methods will require different periods of growth and cycles of production to obtain the seed size needed to produce ware yam. Hence, though traditional methods of production generally have the lowest rate of multiplication compared to modern methods, they produce recommended seed yam sizes in one season of 5 to 12 months, whereas the aeroponics system with a much higher rate of multiplication will produce microtubers that must be planted for another season or two before seed for ware tuber production can be obtained.
The multiplication ratio of the production methods increases with increase in the level of expertise required for production, and the highest ratio obtained is from tissue culture, which is capable of producing the best quality of seed tubers. In traditional methods, the crop stays in the field throughout the season of 28-40 weeks depending on the variety and at harvest, both ware and seed tubers are produced. Plants from minisetts are usually ready for harvest at 20-24 weeks after planting and produce seed tubers, although minisett size can be manipulated to also produce small ware sized tubers. In tissue culture, aeroponics and bioreactors, controlled environments are used and senescence is delayed, but the microtubers produced must be planted for another season or two before regular seed sized tubers can be obtained. If vine cuttings are taken and planted in the field early, normal seed sized tubers can be obtained, but if they are collected when the mother plant is already producing tubers, then microtubers will be obtained at harvest. Apart from tissue culture where viruses can be diagnosed and eliminated, in the other methods of producing seed yam, the health status of the crop must be monitored by focusing on the control of fungi, bacteria, nematodes and insects.

\section{Conclusion and perspectives for the future}

As an important staple for an increasing population of people in West Africa, yam will likely continue to be cultivated using traditional methods of obtaining seed until better options that the yam producers can rely on are made available. The aim of searching for new seed yam production technologies is mainly to transform the seed yam system by making quality seed readily available and developing a formal system which could be a source of good planting material to occasionally replace degraded farmer-saved seed. The traditional methods of production have thrived due to the absence of a formal seed yam

Table 1 Some characteristics of different yam propagation methods

\begin{tabular}{|c|c|c|c|c|c|}
\hline Method of production & Starting material & $\begin{array}{l}\text { Rate of } \\
\text { multiplication }\end{array}$ & Product & $\begin{array}{l}\text { Relative centralization } \\
\text { of technology }\end{array}$ & $\begin{array}{l}\text { Quality of } \\
\text { produce }^{\mathrm{a}}\end{array}$ \\
\hline Traditional & 200-500 g tuber/piece & $1: 4-1: 8$ & Ware and seed tubers & Low & Low \\
\hline Minisett Technique & $25-100 \mathrm{~g}$ tuber piece & $1: 30$ & Seed tubers & Low & Low to Medium \\
\hline Microsetts/Microtubers & $<10 \mathrm{~g}$ tuber $/$ piece & $1: 90$ & Seed tubers & Medium & Low to Medium \\
\hline Tissue culture & Tissues, organs, groups of organs & $1: 1800$ & Microtubers and plantlets & High & High \\
\hline Vine cuttings & Single node vine cuttings & $1: 900$ & Micro and mini-tubers & Medium & Low to medium \\
\hline Aeroponics system & Two-node Vine cuttings & $1: 540$ & Microtubers & High & Medium \\
\hline Bioreactor system & Nodes, buds & $1: 1800$ & Microtubers and plantlets & High & High \\
\hline
\end{tabular}

${ }^{\mathrm{a}}$ The quality of produce generally depends on the quality of the planting material. In production by tissue culture, virus indexing can be done for viruses and other endophytes to ensure that they have been eliminated, while for other methods the material is multiplied in its prevailing state of health 
system that emphasizes quality. As the informal system is not publicly regulated, the quality in terms of health and varietal purity of seed, which the system provides, is not guaranteed. Among the traditional methods, the use of small whole tubers, which are sorted from a ware crop, appears the best, provided their small size is not due to viral disease. It is therefore necessary to provide extension messages which advise farmers against the use of seed tubers from obviously diseased plants and should be tagged during the period of vegetative growth.

Regenerated tubers from double harvesting are less prone to infection by nematodes and are hardy, although their production is labour intensive. If affordable artificial means to influence dormancy are developed, planting dates could be more flexible, and farmers may not have to 'milk' tubers to fetch the usual higher price of early yams. Harvesting the crop once would reduce the cost of production and make more tubers available for food. Using the proximal region of the tuber alone poses higher risks of nematode infection, while setts from other sections of the tuber increase the problem of uneven sprouting and reduce the quantity of tubers that could be used for food. The traditional systems of production fits in very well with current production practices but, to improve seed quality, they should be linked to modern methods that can 'clean' the seed from a build-up of viruses. The modern seed production methods of vine cutting, tissue culture, and aeroponics and temporary immersion bioreactor systems are more suitable for use in a formal seed system where they could supply pre-basic, basic and certified seeds. Farmers would then have the option of renewing their seed stock by buying certified seed when the productivity of their seed has gone below an economic threshold.

The minisett technique, which is the only development for use at the farmer's level, needs more study, taking into account the production practices of farmers of the various yamproducing regions. Promotion of the technique should be targeted at late maturing varieties in single harvest systems. Farmers should be informed of the possible flexibilities of the system; modifications can be made in terms of sett size, sett treatment, population density, staking, etc. If consumers could accommodate smaller sized tubers for food, as is the case in certain urban centres in Nigeria, the minisett size could be adjusted to produce both seed and ware tubers in one season. Yam breeding programmes should breed for suitability to rapid multiplication - ease of sprouting of cut setts, and multiple tuber production [i.e., one major tuber plus one or two seed size tuber(s)]. There is also a need for further research to improve and promote the use of the non-food parts of yam (e.g., the vine and the peel) as alternative means of propagating the crop commercially. This will release a large proportion of the produce which is currently used as seed for food. The choice of the method of production should be guided by the costs involved as the farmers' ability to pay for seed yam is paramount, and there is always the option of saving seed from a previous harvest for use during the next season.

From the foregoing, only an integrated multiplication scheme that combines two or more methods of seed yam production should be adopted in building and sustaining a viable seed yam production system. Nonetheless, it is recommended that tissue culture should form part of any major seed yam production scheme due to its importance in producing and maintaining a nucleus of clean material.

Open Access This article is distributed under the terms of the Creative Commons Attribution 4.0 International License (http:// creativecommons.org/licenses/by/4.0/), which permits unrestricted use, distribution, and reproduction in any medium, provided you give appropriate credit to the original author(s) and the source, provide a link to the Creative Commons license, and indicate if changes were made.

\section{References}

Acha, I. A., Shiwachi, H., Asiedu, R., \& Akoroda, M. O. (2004). Effect of auxins on root development in yam (Dioscorea rotundata) vine. Tropical Science, 44, 80-84.

Adelberg, J. W., \& Simpson, E. P. (2002). Intermittent immersion vessel apparatus and process for plant propagation. In J. Aitken-Christie, T. Kozai \& M. A. L. Smith (Eds.), Automation and environmental control in plant tissue culture (pp. 19-26). The Netherlands: Kluwer Academic Publishers.

Agele, S. O., Ayankanmi, T. G., \& Kikuno, H. (2010). Effects of synthetic hormone substitutes and genotypes on rooting and mini tuber production of vines cuttings obtained from white yam (Dioscorea rotundata, Poir). African Journal of Biotechnology, 9(30), 4714- 4724.

Aighewi, B.A. (1998). Seed yam (Dioscorea rotundata Poir.) production and quality in selected yam zones of Nigeria. Ph.D. thesis, University of Ibadan, Ibadan, Nigeria. Pp 252.

Ajieh, P. C. (2012). Adoption of yam (Dioscorea spp.) minisett technology in Delta State, Nigeria. Agricultura Tropica et Subtropica, 45(2), 84-88.

Akoroda, M. O. (1985a). Dynamics of sprout emergence in Guinea yams. Zeitschrift fur Acker und Pflanzenbau (Journal of Agronomy and Crop Science), 154, 16-24.

Akoroda, M. O. (1985b). Sexual seed production in white yam. Seed Science and Technology, 13, 571-581.

Alvarez, M. N., \& Hahn, S. K. (1984). Seed yam production. In E. R. Terry, E. V. Doku, O. B. Arene, \& N. M. Mahungu (Eds.), Tropical root crops: Production and uses in Africa (pp. 129-132). Ottawa: Proc. 2nd triennial symp. of ISTRC-AB, IDRC-221e.

Amusa, N.A., Adegbite, A.A., Muhammed, S., \& Baiyewu, R.A. (2003). Yam diseases and its management in Nigeria. African Journal of Biotechnology, 2(12), 497-502, December 2003 Available online at http://www.academicjournals.org/AJB. ISSN 1684-5315 C 2003 Academic Journals.

Asala, S., Alegbejo, M. D., Kashina, B., Banwo, O. O., Asiedu, R., \& Lava-Kumar, P. (2012). Distribution and incidence of viruses infecting yam (Dioscorea spp.) in Nigeria. Global Journal Bio-Science and Biotechnology, 1(2), 163-167. ISSN 2278 - 9103 Shaw, Sydney. 2012. 
Ayankanmi, T., Shiwachi, H., \& Asiedu, R. (2005). Sprouting and yield of yam (Dioscorea spp.) minisetts in relation to sett size, soil moisture and agro-ecology. Tropical Science, 45, 23-27.

Balogun, M.O. (2005). Development of microtuber production and dormancy control protocols for yams (Dioscorea spp) germplasm conservation. Ph.D. Thesis. University of Ibadan, Nigeria.

Balogun, M. O. (2009). Microtubers in yam germplasm conservation and propagation: the status, the prospects and the constraints. Biotechnology and Molecular Biology Reviews, 4(1), $1-10$.

Balogun, M.O., \& Gueye, B. (2013). Status and prospects of biotechnology applications to conservation, propagation and genetic improvement of yam. In K.G. Ramawat, \& J-M Merillon (Eds.), Bulbous Plants: Biotechnology (pp. 92-112). CRC Press.

Balogun, M. O., Ng, S. Y. C., Shiwachi, H., Ng, N. Q., \& Fawole, I. (2004). Comparative effects of genotypes and explant source on microtuberization in yams (Dioscorea spp.). Tropical Science, 44, 196-200.

Balogun, M. O., Maroya, N., \& Asiedu, R. (2014). Status and prospects for improving yam seed systems using temporary immersion bioreactors. African Journal of Biotechnology, 13(5), 1614-1622.

Barker, B. T. P. (1922). Studies on root development. Long Ashton Research Station; Annual Report, 1921, 9-57.

Cabanillas, E., \& Martin, F. W. (1978). The propagation of edible yams from cuttings. Journal of Agriculture-University of Puerto Rico, 62(3), 249-254.

Carter, W. A. (1942). A method of growing plants in water vapor to facilitate examination of roots. Phytopathology, 732, 623-625.

Chikwendu, D. O., Chinaka, C. C., \& Omotayo, A. M. (1995). Adoption of minisett technique of seed yams production by farmers in the eastern forest zone on Nigeria. Discovery and Innovation, 7(4), 367-375.

Craig, J. (1964). Studies of a mosaic disease of white yam (Dioscorea rotundata) in Western Region of Nigeria. Cited in: Emehute, J.K.U., Ikotun, T., Nwauzor, E.C. and Nwokocha, H.N. 1998. In Orkwor, G.C., Asiedu, R. \& Ekanayake, I.J. (Eds.), Crop protection. In: Food yams: Advances in research (pp. 141-186).

Curtis, W. R. (2005a). Application of bioreactor design principles to plant micropropagation. Plant Cell Tissue and Organ Culture, 81(3), 255-264

Curtis, W.R. (2005b). Application of bioreactor design principles to plant micropropagation. In Hvoslef-Eide, K., Preil, W. (eds), Chapter 2: Liquid systems for in vitro plant Propagation (pp. 21-40) Springer.

Curtis, M. (2013). Novel temporary immersion bioreactor allows the manipulation of headspace composition to improve plant tissue propagation. Dissertation. Penn State University: University Park, PA.

Degras, L. (1993). In C. Réné (Ed.), The yam: A tropical crop. London: Macmillan Press Ltd. 409 p.

Escalona, M. (2006). Temporary inmersion beats traditional techniques on all fronts. Prophyta Annual, 48-50.

FAO (2013). Food and agricultural organization of the United Nations. www.fao.org/statistics/en/ FAO, Rome

George, J. (1990). Effect of minisett sizes and nursery media on the sprouting of yams. Journal of Root Crops, 16(2), 71-75.

IITA (1985). Root and tuber improvement program. International Institute of Tropical Agriculture. Research Highlights 1981-1984, Ibadan, Nigeria.

IITA. (1986). Annual report of the root and tuber improvement program. Ibadan: International Institute of Tropical Agriculture.

IITA (2013a). Growing seed yams in the air. In IITA weekly Bulletin No 2175 of 3-7 June 2013. Page 3-4.

IITA (2013b). Researchers successfully grow seed yam in the air. In IITA weekly Bulletin No 2204 of 16-20 December 2013. Front page.
Kalu, B. A., Norman, J. C., Pal, V. R., \& Adedzwa, D. K. (1989). Seed yam multiplication by the mini-sett technique in three yam species in a tropical guinea savanna location. Experimental Agriculture, 25, 181-188.

Kikuno, H., Matsumoto, R., Shiwachi, H., Youohara, H., \& Asiedu, R. (2007). Comparative effects of explants sources and age of plant on rooting, shooting and tuber formation of Vine cutting of yams. Japanese Journal of Tropical Agriculture, 51(2), 71-72.

Kissiedu, A. F. K., Okoli, O. O., Asare-Bediako, M., Lamptey, J. N. L., \& Danso, A. K. (1994). Ghana root and tuber crops research. In M. O. Akoroda (Ed.), Root crops for food security in Africa (pp. 435-440). Kampala: Proc. 5th Triennial Symp. of ISTRC-AB.

Kossou, D. K. (1990). Evaluation de practiques culturales relatives à la production de semenceaux et tubercules d'ignames (Dioscorea rotundata) au Bénin. Tropicultura, 8(2), 69-73.

Maroya, N., Balogun, M., \& Asiedu, R. (2014). Seed Yam production in aeroponics system: a novel technology. YIIFSWA Working Paper No 2. Institute International of Tropical Agriculture, Ibadan, Nigeria. 9 pp.

$\mathrm{Ng}$, S. Y. C. (1994). Production and distribution of virus-free yam (Dioscorea rotundata Poir.). In F. Ofori \& S. K. Hahn (Eds.), Tropical root crops in a developing economy (pp. 324-328). Accra: Proc. 9th Symp. of ISTRC.

Nweke, F.I., Ugwu, B.O., Asadu, C.L.A. \& Ay, P. (1991). Production cost in the yam based cropping systems of southeastern Nigeria. $R C P M$ Research Monograph No. 6. International Institute of Tropical Agriculture, Ibadan, Nigeria. 29pp.

Okoli, O. O., \& Akoroda, M. O. (1995). Providing seed tubers for the production of food yams. Africa Journal of Root and Tuber Crops, $1(1), 1-6$.

Okonmah, L. U. (1980). Rapid multiplication of yams (Manual Sieries No. 5). Ibadan: International Institute of Tropical Agriculture.

Onwueme, I. C. (1973). The tropical tuber crop: Yams, cassava, sweet potato, cocoyam. English language book society and John. Chichester: Wiley \& Sons.

Onwueme, I.C. \& Charles, W.B. (1994). Tropical root and tuber crops Production, perspectives and future prospects. F.A.O. Plant Production and Protection Paper 126. Food and Agriculture Organization of the United Nations, Rome.

Otoo, J. A. (1992). Substitutes for chemicals, sawdust and plastic mulch in improved seed yam production. In M. O. Akoroda \& O. B. Arene (Eds.), Promotion of root crop-based industries: An incentive for research and development (pp. 281-284). Kinshasa: Proc. 4th Triennial Symp. of ISTRC-AB.

Otoo, J. A., Osiru, D. S. O., Ng, S. Y., \& Hahn, S. K. (1987). Improved technology for seed yam production. Ibadan: International Institute of Tropical Agriculture. $56 \mathbf{~ p .}$

Sadik, S., \& Okereke, O. U. (1975). Flowering, pollen grain germination, fruiting, germination and seedling development of yam (Dioscorea rotundata Poir.). Annals of Botany, 39, 597-604.

Shaw, S. (2012). An improved temporary immersion bioreactor design for plant tissue culture propagation. Dissertation. Penn State University: University Park, PA.

Watt, M. P. (2012). The status of temporary immersion system (TIS) technology for plant micropropagation. African Journal of Biotechnology, 11(76), 14025-14035.

Xiao, Y., \& Kozai, T. (2004). Commercial application of a photoautotrophic micropropagation system using large vessels with forced ventilation: plantlet growth and production cost. HortScience, 39(6), 1387-1391.

Yam, T. W., \& Arditti, J. (2009). History of orchid propagation: a mirror of the history of biotechnology. Plant Biotechnology Reports, 3, 1-56. 


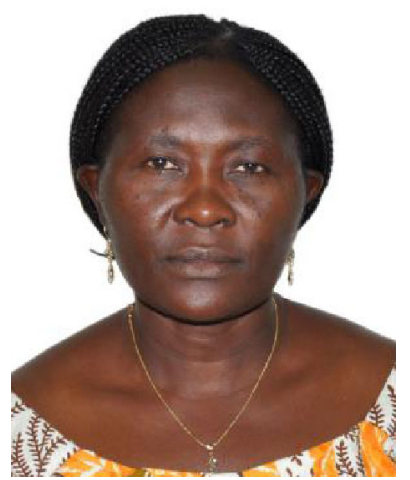

Dr. Beatrice Aighewi is an Agronomist and Yam Seed System Specialist of the 'Yam Improvement for Income and Food Security in West Africa (YIIFSWA)' project of the International Institute of Tropical Agriculture (IITA). She coordinates the seed yam production activities of project partners in Nigeria and Ghana. She obtained a $\mathrm{PhD}$ (Agronomy) at the University of Ibadan, Nigeria, M.Sc. (Agronomy) and B.Sc. (Agriculture) from Ahmadu Bello University, Zaria, Nigeria. She was a Lecturer at the University of Dschang, Cameroon (1987-2007) and University of Abuja, Nigeria (2008-2012). Her research activities are on the propagation of tropical root and tuber crops with a focus on yam.

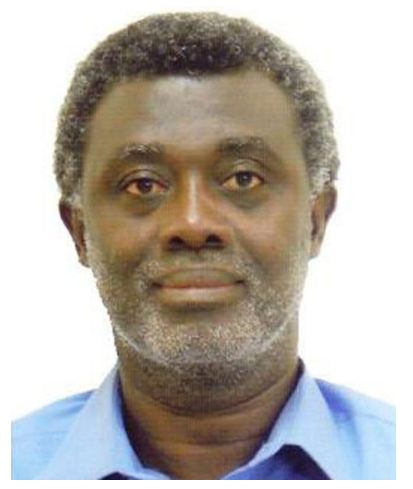

Dr. Robert Asiedu is the Director for West Africa within the Research-for-Development Directorate of the International Institute of Tropical Agriculture (IITA). He obtained a PhD in Agricultural Science in 1987 from the University of Adelaide, Australia after a BSc (Honors) in Agricultural Science in 1979 from the Kwame Nkrumah University of Science and Technology, Kumasi, Ghana. He worked as a Postdoctoral Research Fellow at the International Maize and Wheat Improvement Center (CIMMYT) during 1987 and 1988 before joining IITA in 1989 as a breeder of root and tuber crops with initial focus on cassava and then on yam.

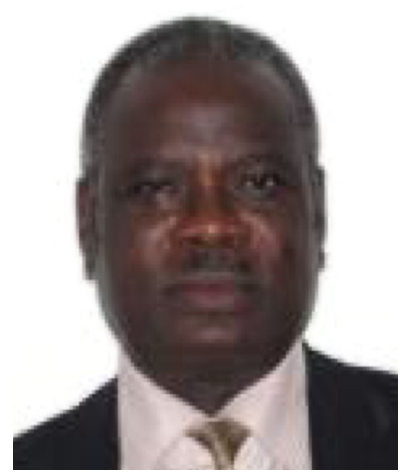

Dr. Norbert G. Maroya is the Project Manager of the Yam Improvement for Income and Food security in West Africa. He obtained a PhD in Plant Breeding in March 2008 from the University of Ghana Legon. He has worked for a total of 29 years in agricultural research in various positions including 15 years as head of the cassava breeding program in the National Agricultural Research Institute of Benin (INRAB) his country of origin. In the last 14 years he has gained regional and international experiences in seed technology, project coordination, cassava breeding and project management.

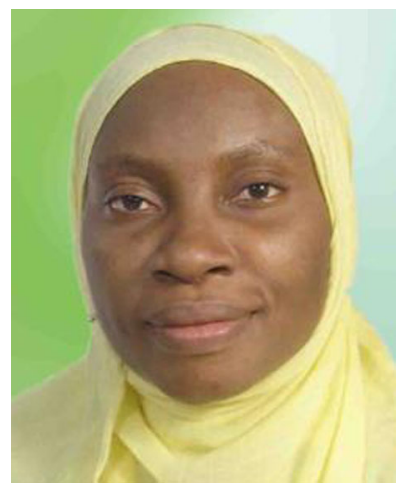

Dr. Morufat Balogun is a Visiting Tissue Culture Specialist at IITA Ibadan, Nigeria. She obtained a Bachelor of Technology (Hons) degree in Pure \& Applied Biology from Ladoke Akintola University of Technology, Ogbomosho, Nigeria, M.Sc. and $\mathrm{PhD}$ in Crop Protection and Environmental Biology (Genetics) from the University of Ibadan where she is a Senior Lecturer. She was a Fellow, United Nations University/Institute for Natural Resources in Africa (2000); Visiting Research Student, IITA, (2000-2005); Norman Borlaug International Science and Technology Fellow (2005). Her research activities include optimization of protocols for in vitro culture of plants for rapid propagation, focusing on bioreactor systems. 